\title{
Pemenuhan Hak Bagi Masyarakat Adat Oleh Negara Di Bidang Hutan Adat
}

\author{
Muhammad Risky Surya Pratama, Arum Ayu Lestari, dan Rimas Intan Katari \\ Fakultas Hukum Universitas Airlangga Surabaya Jawa Timur Indonesia \\ Jln. Airlangga No. 4 - 6, Airlangga Gubeng Surabaya Jawa Timur Indonesia \\ m.rizky.surya-2019@fh.unair.ac.id; arumayu4@gmail.com; rimas.intan.k-2019@fh.unair.ac.id
}

Received: 22 November 2020; Accepted: 18 November 2021; Published: 31 Januari 2022

DOI: 10.20885/iustum.vol29.iss1.art9

\begin{abstract}
The purpose of this research is firstly, to examine the applicability of the Forestry Law in fulfiling the right to prosperity for indigenous peoples as regulated in Article 33 paragraph (3) of the 1945 Constitution of the Republic of Indonesia. Second, as a material for evaluation and recommendation of the Forestry Law so that the state can provide protection for the prosperity of indigenous peoples. The research method used is a normative research with statutory and case approaches. The results of the study conclude that first, in reality the Government has made regulations relating to the protection of the prosperity of indigenous peoples, both in terms of personal and material assets, especially cultural forests. However, there are still many policies from officials and individuals that are not in accordance with the regulations that have been enacted. Such as the case regarding land conflicts in the Pubabu Cultural Forest in Linamnutu Village. Second, there is still a need to expand the scope of legal assistance for indigenous peoples. Decisions regarding the status of cultural forests should not be viewed solely from administrative interests. This status must be seen from the perspective of human rights, especially the perspective of economic, social and cultural rights. In addition, the phrase "in accordance with the development of society and not against the principles of the Indonesian state" must also be given an applicable explanation, as this limitation can be used to reduce customary rights arbitrarily.
\end{abstract}

Key Words: Indigenous peoples; forest; protection guarantee; state responsibility

\section{Abstrak}

Tujuan penelitian ini pertama, untuk menelaah keberlakuan Undang-Undang Kehutanan dalam memenuhi hak kemakmuran bagi masyarakat adat sebagaimana diatur dalam pasal 33 ayat (3) Undang-Undang Dasar Negara Republik Indonesia Tahun 1945. Kedua, sebagai bahan evaluasi dan rekomendasi terhadap Undang-Undang Kehutanan agar negara dapat memberikan perlindungan atas kemakmuran masyarakat hukum adat. Metode penelitian yang digunakan adalah metode penelitian normatif dengan pendekatan perundang-undangan dan pendekatan kasus. Hasil penelitian menyimpulkan bahwa, pertama, pada realitanya Pemerintah telah membuat peraturan-peraturan yang berkaitan dengan perlindungan atas kemakmuran masyarakat hukum adat baik dari segi pribadi maupun harta kebendaannya khususnya hutan adat. Meskipun demikian, masih banyak kebijakan dari pejabat dan oknum yang tidak sesuai dengan peraturan yang telah ditetapkan. Seperti halnya kasus-kasus mengenai konflik tanah di Hutan Adat Pubabu di Desa Linamnutu. Kedua, masih perlu diperluas mengenai bantuan hukum untuk masyarakat adat. Putusan mengenai status hutan adat seharusnya tidak semata-mata dilihat dari kepentingan administratif. Status tersebut harus dilihat dalam perspektif hak asasi manusia terutama perspektif hak ekonomi, sosial dan budaya. Di samping itu, frase "sesuai dengan perkembangan masyarakat dan tidak bertentangan dengan prinsip negara Indonesia" juga harus diberikan penjelasan yang aplikatif, karena pembatasan ini bisa digunakan untuk melakukan pengurangan atas hak adat secara sewenang-wenang.

Kata-kata Kunci: Masyarakat adat; hutan; jaminan perlindungan; pertanggungjawaban negara 


\section{Pendahuluan}

Pada alinea ke IV Pembukaan Undang-Undang Dasar Negara Republik Indonesia Tahun 1945 (UUD NRI 1945) telah sangat jelas menyebutkan tujuan dari pembentukan negara ini yaitu untuk "melindungi segenap bangsa Indonesia dan seluruh tumpah darah Indonesia dan untuk memajukan kesejahteraan umum, mencerdaskan kehidupan bangsa dan ikut melaksanakan ketertiban dunia yang berdasarkan kemerdekaan, perdamaian abadi dan keadilan sosial." Selanjutnya Pembukaan UUD NRI 1945 ini menjadi rumusan dari Pasal 33 ayat (3) UUD NRI 1945. Pasal 33 ayat (3) menjelaskan bahwa "Bumi dan air dan kekayaan yang terkandung didalamnya dikuasai oleh negara dan dipergunakan untuk sebesar-besarnya kemakmuran rakyat".

Hal di atas memberikan arti, bahwa yang terdapat dalam Pembukaan UUD 1945 ini ada kaitannya dengan Pasal 33 ayat (3) UUD NRI 1945 yang ditunjukkan pada kata "kemakmuran rakyat" dengan tujuannya untuk kesejahteraan, yang merdeka, dengan damai serta adil. Rumusan mengenai kemakmuran rakyat ini merujuk pada bagaimana negara bertindak (handling), berfikir (denken), dan berkehendak (willen) terhadap bumi, air dan kekayaan alam yang terkandung di dalamnya untuk masyarakat yang ada di wilayah Negara Kesatuan Republik Indonesia, selanjutnya disebut NKRI. ${ }^{1}$ Pasal 33 ayat (3) UUD 1945 ini menjelaskan bahwa bumi yang kita pijak merupakan hak setiap orang untuk berada di atasnya, untuk bertahan hidup dan memiliki tempat tinggal yang layak. Pasal 33 ayat (3) ini mengandung banyak arti dari Hak Asasi Manusia. Pasal 33 ayat (3) ini merupakan pasal yang menjadi dasar terbentuknya Undang-Undang Nomor 41 Tahun 1999 tentang Kehutanan, yang selanjutnya disebut UU Kehutanan. ${ }^{2}$

UU Kehutanan ini telah digabungkan ke dalam Undang-Undang Nomor 11 Tahun 2020 tentang Cipta Kerja pada Paragraf ke IV tentang Kehutanan Pasal 35. Akan tetapi tujuan dari pembentukan UU Kehutanan ini masih tetap tercantum dalam Pasal 3 yang menyebutkan bahwa "Penyelenggaraan Kehutanan bertujuan

1 Ronald Z. Titahelu, Asas-Asas Hukum Umum Dalam Penggunaan Tanah Untuk Sebesar-besarnya Kemakmuran Rakyat (Suatu Kajian Filsafati dan Teoritik Tentang Pengaturan dan Penggunaan Tanah di Indonesia), e-book https://books.google.co.id , Publish: 13 September 2016, hlm. 2

2 Putusan Mahkamah Konstitusi Republik Indonesia Nomor 35/PUU-X/2012 tentang Pengujian Undang-Undang Nomor 41 tahun 1999 tentang Kehutanan terhadap Undang-Undnang Dasar Negara Republik Indonesia Tahun 1945, hlm. 3 
untuk sebesar-besar kemakmuran rakyat yang berkeadilan dan berkelanjutan" ini mengartikan bahwa hutan digunakan untuk memakmurkan rakyat secara adil dan terus menerus tanpa merusak fungsi hutan yang sesungguhnya. ${ }^{3}$

Pada hakekatnya UU Kehutanan ini dibuat atas dasar mandat dari aturan perundang-undangan juga menyangkut tentang kemakmuran rakyat. Rakyat menjadi tolak ukur di Indonesia ialah yang ada di dalam wilayah Republik Indonesia, termasuk di dalamnya ialah masyarakat adat. Pada kenyataannya, masyarakat adat ada yang hidup di dalam hutan negara dan menjadikan hutan negara sebagai tempat untuk berlindung, berladang, mencari bahan makanan, kayu bakar untuk pemenuhan hajat hidupnya. Dalam pembahasan kali ini, peneliti akan memfokuskan pada hutan adat, di mana dalam pengertiannya, hutan adat merupakan hutan negara dalam wilayah masyarakat adat. ${ }^{4}$

Hutan adat diakui dalam hukum, sebagimana yang telah tercantum dalam UU Kehutanan sendiri dalam Pasal 1 yang telah menjelaskan tentang hutan adat. Sehingga, dapat diartikan bahwa negara mengakui bahwa adanya masyarakat adat yang terdapat di hutan negara. Secara historis sebagaimana yang kita ketahui bahwa masyarakat adat telah ada sebelum negara Indonesia merdeka yang hidup dan beraktivitas di seluruh nusantara. Komunitas-komunitas tersebut mandiri dalam arti mampu memenuhi berbagai kebutuhan fungsi politik, ekonomi, hukum serta fungsi mempertahankan kelangsungan keberadaan komunitas melalui sosialisasi nilai dan tradisi yang dilakukan dari generasi ke generasi. Sehingga tercipta hukum aturan yang berlaku bagi masyarakat adat yang disebut Hukum Adat. Hukum adat adalah aturan yang dibuat berdasarkan pada nilai-nilai budaya masyarakat adat sebagai cerminan dari sesuatu yang dianggap benar, patut dan baik dalam menata hubungan-hubungan mereka dengan lingkungan sosialnya maupun lingkungan alam fisiknya seperti tanah. Dalam menata hubungan sosial dan fisik telah melahirkan pranata-pranata hukum adat seperti hukum kekerabatan (kinship), hukum perkawinan, hukum waris, hukum delik, hukum tanah dan sebagainya. Karena keberadaan masyarakat adat lebih dulu dibandingkan lahirnya negara Indonesia. Dalam

\footnotetext{
${ }^{3}$ Undang-Undang Nomor 41 Tahun 1999 tentang Kehutanan.

${ }^{4}$ Undang-Undang Nomor 41 Tahun 1999 tentang Kehutanan.
} 
seminar Hukum Adat 1975 di Jogjakarta, hukum adat dinyatakan sebagai hukum asli atau aturan asli bagi negara Indonesia akan tetapi tidak berbentuk perundang-undangan yang mengandung unsur agama.

Pada kenyataannya, semenjak berlakunya UU kehutanan, pemerintah lebih menjadikan UU Kehutanan ini sebagai alat negara untuk mengambil alih hak kesatuan dari masyarakat adat atas wilayah hutan adat, untuk dijadikan sebagai hutan negara, yang selanjutnya atas nama negara diberikan dan/atau diserahkan kepada pemilik modal melalui skema perizinan untuk dieksploitasi tanpa memperhatikan hak serta kearifan lokal dari kesatuan masyarakat adat di wilayah tersebut. ${ }^{5}$ Sehingga menurut peneliti hal ini akan menimbulkan tidak terpenuhinya hak atas kemakmuran bagi masyarakat adat sebagaimana yang tercantum dalam Pasal 33 ayat (3) UUD 1945 yang menjadi dasar lahirnya UU Kehutanan.

\section{Rumusan Masalah}

Adapun rumusan masalah yang dapat dijabarkan sebagai berikut. Pertama, apakah UU Kehutanan ini merupakan dasar yang dapat memenuhi hak kemakmuran bagi masyarakat adat, sebagaimana yang telah termuat dalam Pasal 33 ayat (3) UUD 1945? Kedua, apakah evaluasi dan rekomendasi terhadap Undang-Undang Kehutanan agar Negara dapat memberikan perlindungan atas kemakmuran masyarakat hukum adat?

\section{Tujuan Penelitian}

Adapun tujuan dari penelitian ini, sebagaimana yang didasarkan dari rumusan masalah yang peneliti cantumkan, yakni: Pertama, untuk menelaah dan memahami tentang UU Kehutanan dalam pemenuhan hak kemakmuran bagi masyarakat adat sebagaimana yang diatur dalam Pasal 33 ayat (3) UUD 1945. Kedua, untuk bahan evaluasi dan rekomendasi terhadap Undang-Undang Kehutanan agar Negara dapat memberikan perlindungan atas kemakmuran masyarakat hukum adat.

5 Putusan Mahkamah Konstitusi Nomor 35/PUU-X/2012 tentang Pengujian Undang-Undang Nomor 41 Tahun 1999 tentang Kehutanan terhadap Undang-Undnang Dasar Negara Republik Indonesia Tahun 1945, hlm. 3 . 
Metode Penelitian

Penelitian ini merupakan penelitian hukum secara normatif yang dimana menggunakan pendekatan perundang-undangan dan kasus.

\section{Pembahasan dan Hasil Penelitian}

\section{Jaminan Hak Kemakmuran Masyarakat Adat dalam Peraturan Perundang- undangan}

Istilah masyarakat hukum adat tidaklah asing bagi kebanyakan orang, terutama di Indonesia, pengertian masyarakat hukum adat banyak ditemukan di berbagai literatur bahkan dalam perundang-undangan. Di dalam sebuah buku berjudul Beginselen et Stelsel van het Adatrech, Ter Haar mengatakan bahwa “... geordende groepen van blijvend karakter met eigen bewind en eigen materleel en immateriel vermogen" yang dalam Bahasa Indonesia diartikan kurang lebih seperti ini “... kelompok-kelompok teratur yang sifatnya ajek dengan pemerintahan sendiri yang memiliki benda-benda materiil maupun immateriil."6 Sedangkan di dalam Undang-Undang Nomor 32 Tahun 2009 tentang Perlindungan dan Pengelolaan Lingkungan Hidup selanjutnya disebut dengan UU PPLH, dijelaskan bahwa Masyarakat Hukum Adat adalah kelompok masyarakat yang hidup secara turun temurun dan bermukim di wilayah tertentu karena terdapat sebuah ikatan dari para leluhur, dan dalam kelompok tersebut terdapat sistem nilai yang dapat menentukan sebuah ekonomi, politik, sosial dan hukum. Hal ini akan tetap diakui sepanjang masih hidup dan sesuai dengan perkembangan masyarakat dan prinsip Negara Kesatuan Republik Indonesia. Hal ini senada dengan Pasal 67 ayat

(1) UU Kehutanan dikatakan bahwa:

Masyarakat hukum adat sepanjang menurut kenyataannya masih ada dan diakui keberadaannya berhak:

a) Melakukan pemungutan hasil hutan untuk pemenuhan kebutuhan hidup sehari-hari masyarakat adat yang bersangkutan;

b) Melakukan kegiatan pengelolaan hutan berdasarkan hukum adat yang berlaku dan tidak bertentangan dengan undang-undang; dan

c) Mendapatkan pemberdayaan dalam rangka meningkatkan kesejahteraannya. Bahkan, hak masyarakat hukum adat juga diakui dan diatur di dalam sebuah perundang-undangan yakni dalam UUD 1945 Pasal 18B ayat (2) dijelaskan bahwa

${ }^{6}$ Soejarno Soekanto, Hukum Adat Indonesia, Raja Grafindo, Jakarta, 2012, hlm. 93 
"Negara mengakui dan menghormati kesatuan-kesatuan masyarakat hukum adat beserta hakhak tradisionalnya sepanjang masih hidup dan sesuai dengan perkembangan masyarakat dan prinsip Negara Kesatuan Republik Indonesia, yang diatur dalam undang-undang."

Masyarakat hukum adat hidup di sebuah wilayah hutan yang disebut dengan hutan adat, berdasarkan Pasal 1 angka 6 UU Kehutanan dijelaskan bahwa hutan adat adalah hutan negara yang berada dalam wilayah masyarakat hukum adat, kemudian setelah adanya Putusan Nomor 35/PUU-X/2012 dijelaskan Mahkamah Konstitusi menegaskan bahwa hutan adat bukan merupakan hutan negara, hal ini dikarenakan Pasal 1 angka 6 UU Kehutanan bertentangan dengan UUD 1945 Pasal 18B ayat (2) mengenai eksistensi penghormatan terhadap hakhak masyarakat adat, maka dari itu dalam hal ini negara tidak memiliki kekuasaan hukum untuk menjadikan hutan adat adalah hutan yang berada di wilayah masyarakat hukum adat menjadi hutan negara.7 Tidak hanya berkaitan dengan hutan adat, dalam undang-undang tersebut juga dijelaskan beberapa pengertian dan pembagian hutan yang terdapat di dalam Pasal 1 UU kehutanan:

1. Hutan Negara adalah hutan yang berada pada tanah yang tidak dibebani hak atas tanah

2. Hutan Hak adalah hutan yang berada pada tanah yang dibebani hak atas tanah

3. Hutan Produksi adalah kawasan hutan negara yang berada dalam wilayah masyarakat hukum adat

4. Hutan Produksi adalah Kawasan hutan yang mempunyai fungsi pokok memproduksi hasil hutan

5. Hutan Lindung adalah Kawasan hutan yang mempunyai fungsi pokok sebagai perlindungan sistem penyangga kehidupan untuk mengatur tat air, mencegah banjir, mengendalikan erosi, mencegah intrusi air laut dan memelihara kesuburan tanah.

6. Hutan Konservasi adalah Kawasan hutan dengan ciri khas tertentu yang mempunyai fungsi pokok pengawetan keanekaragaman tumbuhan dan satwa beserta ekosistemnya.

Dengan adanya pembagian berbagai macam hutan tersebut, seharusnya negara lebih mengetahui batasan-batasan dalam memanfaatkan fungsi dan sumber daya alam yang ada di hutan, jangan sampai pemanfaatan tersebut merugikan masyarakat terutama bagi masyarakat hukum adat yang tinggal di dalam hutan adat, karena Pasal 33 ayat (3) UUD 1945 menyebutkan bahwa "bumi, air, dan

\footnotetext{
${ }^{7}$ Cunduk wasiati dan Hartanto, "Perizinan Sebagai Instrumen Pemanfaatan Hutan Masyarakat Hukum Adat”, Jurnal Meta Yuridis, Vol.3 No.1, 2020, hlm. 99.
} 
kekayaan yang terkandung di dalamnya dikuasai oleh negara dan dipergunakan sebesar-besar untuk kemakmuran rakyat" hal ini juga dijelaskan di dalam Pasal 4 UU Kehutanan yang mengatakan "Semua hutan di dalam wilayah republik Indonesia termasuk kekayaan alam yang terkandung di dalamnya "dikuasai" oleh negara untuk sebesar-besar kemakmuran rakyat".

Penguasaan demi kemakmuran rakyat menjadi frasa yang doktrinal, sebagaimana diketahui bahwa UUD 1945 menjadi dasar dan landasan setiap dibentuknya peraturan-peraturan baru, konteks sebesar-besar kemakmuran rakyat dalam konteks konstitusi secara pribadi tanpa adanya suatu tafsiran yang jelas berkaitan dengan frasa "sebesar-besar kemakmuran rakyat" menjadi poin terlemah dari Pasal 33 ayat (3) tersebut. Karena ketika batas-batas tidak diketahui secara rinci inilah yang menyebabkan atau dapat menjadi cikal bakal terjadinya pembentukan peraturan yang tidak sesuai atau bahkan biasa saja peraturan tersebut digunakan untuk memenuhi atau mendapatkan keuntungan pribadi bagi para penguasa maupun pengusaha dengan dalih demi kemakmuran rakyat.

Melalui Putusan Mahkamah Konstitusi Nomor 001-021-022/PUU-1/2003 memberikan tafsir atas frasa "dikuasai oleh negara" dalam Pasal 33 UUD 1945 perkataan "dikuasai oleh negara" haruslah diartikan mencakup makna penguasaan oleh negara dalam arti luas yang bersumber dan berasal dari konsepsi kedaulatan rakyat Indonesia atas segala sumber kekayaan alam yang terkandung di dalamnya," berdasarkan hal tersebut maka terdapat sebuah kandungan di dalamnya yang memberikan pengertian bahwa adanya kepemilikan secara publik atau kolektivitas bagi rakyat, sehingga rakyat secara tidak langsung telah memberikan mandat atau mempercayakan kepada negara untuk mengadakan kebijakan (beleid), tindakan pengurusan (bestuursdaad), pengaturan (regelendaad), pengelolaan (beheersdaad), dan pengawasan (toezichthoudensdaad) untuk tujuan sebesar-besarnya bagi kemakmuran rakyat. ${ }^{8}$

Dalam bidang kehutanan sesuai Pasal 4 UU Kehutanan dinyatakan bahwa semua hutan di dalam wilayah Republik Indonesia termasuk kekayaan alam yang terkandung di dalamnya oleh negara untuk sebesar-besar kemakmuran rakyat,

${ }^{8}$ Dyah Ayu Widowati, dkk, Pengakuan dan Perlindungan Hak. Atas Tanah Masyarakat Hukum Adat di Kawasan Hutan, Pusat Penelitian dan Pengabdian kepada Masyarakat (PPPM), Yogyakarta, 2019, hlm. 17. 
sehingga penguasaan hutan ini memberikan kewenangan kepada pemerintah agar:

1. Mengatur dan mengurus segala sesuatu yang berkaitan dengan hutan, kawasan hutan dan hasil hutan;

2. Menetapkan status wilayah tertentu sebagai kawasan hutan dan kawasan hutan sebagai bukan kawasan hutan; dan

3. Mengatur dan menetapkan hubungan-hubungan hukum antara orang dengan hutan, serta mengatur perbuatan-perbuatan hukum mengenai kehutanan.

Berdasarkan apa yang telah disampaikan di dalam perundang-undang tersebut, maka negara tidak dapat menguasai secara sewenang-wenang sesuai dengan kehendaknya sendiri melainkan terdapat batasan terhadap perbuatan dan hubungan hukum yang dilakukan negara. Penguasaan oleh negara haruslah secara kausalitas dengan kemakmuran masyarakat bukan secara utilitas, jadi meskipun negara diberikan hak untuk melakukan penguasaan akan tetapi akibat penguasaan negara tersebut tidak menciptakan kemakmuran maka penguasaan yang dilakukan oleh negara tersebut tidak sesuai seperti apa yang diamanahkan dalam Pasal 33 UUD 1945. ${ }^{9}$ Didasarkan pada Putusan Mahkamah Konstitusi Nomor 35/PUUX/2012 menjelaskan, bahwa Mahkamah Konstitusi mengabulkan sebagian Judicial Review UU Kehutanan yang diajukan oleh masyarakat adat nusantara. Putusan MK menegaskan hutan adat bukan merupakan hutan negara. Hal ini dikarenakan negara dalam Pasal 1 angka 6 UU Kehutanan bertentangan dengan UUD 1945 Pasal 18 B ayat (2) mengenai eksistensi penghormatan terhadap hak-hak masyarakat adat. Dalam hal ini negara tidak memiliki kekuasaan hukum untuk menjadikan hutan adat yakni hutan yang berada di wilayah masyarakat hukum adat menjadi hutan negara. Pasal 2 ayat (3) UU Kehutanan juga bertentangan dengan UUD 1945. Sepanjang tidak dimaknai penguasaan hutan oleh negara tetap memperhatikan hak masyarakat hukum adat sepanjang masih hidup dan sesuai perkembangan masyarakat dan prinsip negara yang diatur dalam undang-undang. Pasal 5 ayat (1) dinyatakan bertentangan dengan UUD NRI 1945 dan tidak memiliki kekuatan hukum tetap. ${ }^{10}$

\footnotetext{
${ }_{9}$ Ibid., hlm. 13-14.

10 Putusan Mahkamah Konstitusi Nomor 35/PUU-X/ 2012
} 
Helmi mengatakan bahwa era reformasi bidang kehutanan dengan lahirnya UU No. 41 Tahun 1999 tentang Kehutanan, mengidentifikasikan bahwa undangundang tersebut ternyata "setali tiga uang". Perizinan bidang kehutanan yang mendelegasikan wewenang kepada pemerintah daerah justru makin memperparah kerusakan hutan di Indonesia, bahkan illegal logging, mengalami booming pada kurun waktu 1999 sampai 2004.11 Ketentuan dasar Pasal 33 ayat (3) UUD 1945 memperlihatkan prinsip dasar hubungan antara negara dengan warga masyarakat berkaitan dengan tanah. Dalam ketentuan dasar tersebut, terutama terkandung maksud penghapusan prinsip domeinverkaring yang dikenal pada masa Hindia Belanda, dimana asas ini bertentangan dengan kesadaran hukum masyarakat dan asas ketatanegaraan, dan negara tidak perlu menjadi pemilik tanah. Konteks penguasaan sumber daya alam harus mampu memberikan manfaat yang maksimal bagi seluruh rakyat Indonesia yang merupakan bagian terpenting daripada penguasaan sumber daya alam. Kesejahteraan bukan berarti bahwa sumber daya alam harus dieksploitasi dan menghasilkan secara ekonomis akantetapi sumber daya alam yang merupakan titipan bagi anak cucu harus memberikan manfaat untuk jangka panjang keberadaannya sehingga manfaat yang diterima merupakan manfaat tidak hanya intergenerasi namun juga manfaat antar generasi.

Lahirnya Undang-Undang Cipta Kerja juga mempengaruhi nasib dari kehidupan masyarakat adat terkait tanah yang ditempatinya, ada beberapa perubahan signifikan berkaitan dengan masyarakat hukum adat, misalnya Pasal 69 ayat (2) Undang-Undnag Nomor 32 Tahun 2009 tentang Perlindungan dan Pengelolaan Lingkungan Hidup. Awal mula di dalam Pasal tersebut berbunyi “Ketentuan sebagaimana dimaksud ayat (1) huruf h (adanya Tindakan untuk membuka lahan dengan cara dibakar dan sebaginya) memperhatikan dengan sungguh-sunguh kearifan lokal di daerah masing-masing." Definisi dari kearifan lokal sendiri ialah "adanya pembakaran lahan dibatasi maksimal 2 hektare per kepala keluarga untuk ditanami tanaman jenis varietas lokal dan dikelilingi oleh sekat bakar sebagai pencegah penjalaran api ke wilayah sekelilingnya."12

\footnotetext{
${ }^{11}$ Helmi, Hukum Perizinan Lingkungan Hidup, cetakan I, Sinar Grafika, Jakarta, 2012, hlm. 179.

${ }^{12}$ Nasib Masyarakat Adat dalam UU Cipta Kerja, forestdigest.com, diakses pada 06 April 2021.
} 
Di dalam Undang-Undang Cipta Kerja normanya berubah menjadi "Ketentuan sebagaimana dimaksud ayat (1) huruf $\mathrm{h}$ dikecualikan bagi masyarakat yang melakukan kegiatan dimaksudkan agar memperhatikan dengan sungguh-sunguh kearifan lokal di daerah masing-masing." penjelasan terkait definisi dari "kearifan lokal" berbah menjadi "melakukan pembakaran lahan dengan luas lahan maksimal 2 (dua) hekatare per kepala keluarga untuk ditanami jenis varietas lokal dan dikelilingi oleh sekat bakar sebagai pencegahan penjalaran api disekelilingnya."13

Undang-Undang Cipta Kerja juga memberikan pengertian yang lebih spesiik terkat dengan obyek pengadaan tanah, termasuk di dalamnya adalah tanah adat. Undang-Undang yang mengaturnya sebelumnya berbunyi di dalama Pasal 8 Undang-Undang Nomor 2 Tahun 2012 yakni "Pihak yang berhak dan menguasai obyek Pengadaan Tanah untuk Kepentingan Umum wajib mematuhi ketentuan dalam Undang-Undang ini." Kemudian di rubah sehinga di dalam UU Cipta Kerja berbunyi "Dalam hal rencana Pengadaan Tanah, terdapat Objek Pengadaan Tanah yang masuk dalam kawasan hutan, tanah kas desa, tanah wakaf, tanah ulayat/tanah adat (cetak miring ditambahkan), dan/atau tanah aset Pemerintah Pusat, Pemerintah Daerah, Badan Usaha Milik Negara, atau Badan Usaha Milik Daerah, proses penyelesaian status tanahnya harus dilakukan sampai dengan penetapan lokasi". Dan pengakuan hutan adat harus diakui berdasarkan peraturan daerah tetap dipertahankan, padahal hal tersebut juga masih menimbulkan banyak problematika. Berdasarkan hal-hal yang telah dibahas diatas bahwa hukum masih menimbulkan baik segi positif dan negative. Maka hal tersebut dapat dikaitkan dengan prinsip dari hukum itu sendiri, dalam hal ini terdapat prinsip utilitas Bentham mendasarkan keseluruhan filsafatnya pada dua prinsip yaitu prinsip asosiasi (association principle) dan prinsip kebahagiaan terbesar (greates happiness principle). Prinsip asosiasi berakar pada psikologi tentang adanya reflex yang dikondisikan. Dalam konteks ini Bentham menunjukkan bahwa hukum memiliki kemampuan sebagai stimulus untuk mengkondisikan ide-ide tentang kebaikan. 
Prinsip kedua yaitu prinsip tentang kebahagiaan terbesar. Kesenangan atau kemanfaatan sebagaimana dimaksud diatas dapat diraih dengan ukuran akibat (konsekuensi). Dengan demikian hukum yang baik adalah hukum yang bisa memberikan akibat yang paling bermanfaat atau menimbulkan kebahagiaan terbesar untuk jumlah orang terbesar (the greatest happiness of the greatest number). Kebahagiaan tersebut muncul tidak lepas dari fungsi hukum itu sendiri. Menurut Bentham "All the functions of law may be referred to these four heads: to provide subsistence; to produce abudance; to favour equality; and to maintain security." Selanjutnya dalam memaknai hukum, menurut Bentham hukum yang merupakan sekumpulan tanda (assemblage of sign). Tanda yang dimaksud oleh Bentham adalah ungkapan kehendak (the expression of will) yang muncul dari kehendak yang dipahami dan diserap oleh penguasa negara.

\section{Evaluasi dan Rekomendasi terhadap Undang-Undang Kehutanan agar Negara dapat Memberikan Perlindungan atas Kemakmuran Masyarakat Hukum Adat}

Perkembangan hukum dan masyarakat Indonesia berubah seiring dengan perkembangan bukan saja tuntutan sosial, budaya, ekonomi dan politik, tetapi juga sistem hukum nasional turut berubah pula sehingga ini menjadi bahan evaluasi bagi negara dan pemerintah setempat. Tugas Pemerintah Pusat untuk mengubah masyarakat hukum adat yang memiliki status hukum serta kewenangan menjadi sangat penting agar hak-hak masyarakat adat dapat terpenuhi. ${ }^{14}$ Namun, pada kenyataannya, dalam melakukan berbagai aktivitas ekonomi, sosial dan budaya, masyarakat adat dapat mengalami berbagai hambatan dari pihak ketiga sebagai akibat adanya berbagai peraturan maupun kebijakan Pemerintah dan Pemerintah Daerah yang berkaitan dengan pertanahan, kehutanan dan kelautan yang memberikan ijin pihak ketiga dalam menjalankan aktivitas di wilayah masyarakat adat. Hal ini mengakibatkan masyarakat kehilangan hak-hak dalam melakukan aktivitas ekonomi, sosial dan budaya yang telah dilakukan sejak lama dan turun-temurun. ${ }^{15}$ Eksistensi mereka terancam di

\footnotetext{
${ }^{14}$ Jawahir Thontowi, Perlindungan dan Pengakuan Masyarakat Adat dan Tantangannya dalam Hukum Indonesia, Jurnal Hukum IUS QUIA IUSTUM, Vol. 20, No. 1, 2013, hlm. 23.

${ }^{15}$ Yuliana, Perlindungan Hak Masyarakat Adat dalam Melakukan Aktivitas Ekonomi, Sosial dan Budaya di Provinsi Maluku, Jurnal HAM, Vol. 8, No. 1, 2017, hlm. 3.
} 
tengah banyak upaya penjarahan sumberdaya alam dan pengalihan fungsi hutan yang menyingkirkan hak-hak masyarakat adat salah satunya yaitu hak kemakmuran. Hingga kini, masih banyak masyarakat adat yang terusir dari lahan mereka sendiri akibat ekspansi lahan pertambangan atau perkebunan kelapa sawit skala besar di Kalimantan dan Sumatra.

Permasalahan yang terjadi dengan UU Kehutanan ini adalah adanya inkonsistensi konsepsi mengenai HAM dan penerapannya dalam hak masyarakat adat atas hutan adat. Secara teoritis, mengutip dari definisi HAM, seharusnya hak masyarakat adat dipahami sebagai suatu hak yang melekat kepada masyarakat adat karena memang masyarakat tersebut memenuhi kriteria sebagai masyarakat adat. Akan tetapi, UU Kehutanan ini menyatakan bahwa hak masyarakat adat adalah hak negara yang kebetulan berada di wilayah masyarakat adat. ${ }^{16}$

Pengakuan mengenai eksistensi masyarakat adat sebenarnya telah tertuang dalam dua pasal yang relevan di dalam Bab tentang Hak Asasi Manusia. Pasal 28G ayat (1) berbunyi: "Setiap orang berhak atas perlindungan diri pribadi, keluarga, kehormatan, martabat, dan harta benda yang ada di bawah kekuasaannya serta berhak atas rasa aman dan perlindungan terhadap ancaman ketakutan untuk berbuat atau tidak berbuat sesuatu yang merupakan hak asasi manusia" dan Pasal 28H ayat (4): "Setiap orang berhak mempunyai hak milik pribadi, dan hak milik tersebut tidak boleh diambil alih secara sewenang-wenang oleh siapa pun." Pasal-pasal khusus tentang masyarakat hukum adat merujuk pada Pasal 18B ayat (2) yang menyatakan: "Negara mengakui dan menghormati kesatuan-kesatuan masyarakat hukum adat beserta hak tradisionalnya sepanjang masih hidup dan sesuai dengan perkembangan masyarakat dan prinsip Negara Kesatuan Republik Indonesia yang diatur dalam Undang-undang." dan Pasal 28 I ayat (3): "Identitas budaya dan hak masyarakat tradisional dihormati selaras dengan perkembangan zaman dan peradaban." Sehingga jika dikaitkan dengan Undang-Undang Kehutanan yang sebelumnya bahwa aturan-aturan yang menjadi bahan evaluasi penulis ini lah yang menurut hemat penulis merupakan pasal-pasal yang sering terlupakan sehingga banyak hak kemakmuran rakyat

16 Tobroni, Menguatkan Hak Masyarakat Adat Atas Hutan Adat (Studi Putusan MK Nomor 35/ PUUX/2012), Jurnal Konstitusi, Vol. 10, No. 3, 2013, hlm. 465. 
tidak dipahami dan tidak diketahui sebagimana batasannya. Agar terciptanya aturan tentang Kehutan harusnya dapat menjadikan aturan itu sebagai atauran yang berasaskan Lex Specialis Derogat Leghi Generaly, sehingga batas-batas yang bersifat umum dapat lebih terarah ke batasan yang sangat khusus.

Dari sekian banyaknya aturan yang mengatur tentang pertanahan di Indonesia termasuk pada Undang-Undang Nomor 41 Tahun 1999 tentang Kehutanan, sehingga timbul rekomendasi yang penulis pikirkan agar negara dapat sedikit tidaknya memberikan pemenuhan hak kemakmuran bagi masyarakat adat, ialah dimana ditinjau pasal-pasal yang memberikan posisi konstitusional kepada masyarakat hukum adat dalam hubungannya dengan negara serta menjadi landasan konstusional bagi penyelenggara negara, bagaimana seharusnya masyarakat hukum adat diperlakukan. Pasal tersebut adalah satu pernyataan tentang; (a) kewajiban konstusional negara untuk mengakui dan menghormati masyarakat adat, serta (b) hak konstusional masyarakat hukum adat untuk memperoleh pengakuan dan penghormatan terhadap hak-hak tradisionalnya. ${ }^{17}$ Apa yang termaktub dalam Pasal 18B ayat (2) tersebut sekaligus merupakan mandat konstitusi yang harus dipatuhi oleh penyelenggara negara, untuk mengatur pengakuan dan penghormatan atas keberadaan masyarakat adat dalam suatu bentuk undang-undang Pasal 18B ayat (2) mencantumkan beberapa persyaratan yang harus dipenuhi suatu masyarakat untuk dapat dikategorikan sebagai masyarakat (hukum) adat beserta hak tradisionalnya. Persyaratan-persyaratan itu diantaranya adalah: a.) Sepanjang masih hidup; b.) Sesuai dengan perkembangan masyarakat; c.) Sesuai dengan prinsip NKRI; d.) Diatur dalam Undang-undang. 18

Di dalam UU No. 39 Tahun 1999 tentang HAM mengatur secara menyeluruh hak-hak asasi setiap warga negara Indonesia. Beberapa hak yang berlaku umum yang relevan dengan tata kehidupan masyarakat di dalam dan sekitar hutan adalah sebagai berikut:

\footnotetext{
17 Besse Sugiswati, "Perlindungan Hukum Terhadap Masyarakat Adat Indonesia", Jurnal Prespektif, Surabaya, 2012, hlm. 39 .

18 Ibid.
} 
a. Hak untuk Hidup (Pasal 9)

(1) Hak untuk mempertahankan hidup dan meningkatkan taraf kehidupannya;

(2) Hak hidup tenteram, aman, damai, bahagia, sejahtera lahir dan batin;

(3) Hak atas lingkungan hidup yang bersih dan sehat.

b. Hak atas Kesejahteraan (Pasal 36)

(1) Setiap orang berhak mempunyai milik, baik sendiri maupun bersamasama dengan orang lain demi pengembangan dirinya, keluarga, bangsa, dan masyarakat dengan cara yang tidak melanggar hukum;

(2) Tidak seorang pun boleh dirampas miliknya dengan sewenang-wenang dan secara melawan hukum;

(3) Hak milik mempunyai fungsi sosial;

c. Pasal 38 ayat (1) "Setiap warga negara, sesuai dengan bakat, kecakapan, dan kemampuan, berhak atas pekerjaan yang layak."

d. Hak Memperoleh Keadilan (Pasal 17)

"Setiap orang, tanpa diskriminasi, berhak untuk memperoleh keadilan dengan mengajukan permohonan, pengaduan, dan gugatan, baik dalam perkara pidana, perdata, maupun administrasi serta diadili melalui proses peradilan yang bebas dan tidak memihak, sesuai dengan hukum acara yang menjamin pemeriksaan yang objektif oleh hakim yang jujur dan adil untuk memperoleh putusan yang adil dan benar."

e. Hak atas Rasa Aman (Pasal 29 dan Pasal 33)

Pasal 29 ayat (1) "Setiap orang berhak atas perlindungan diri pribadi, keluarga, kehormatan, martabat, dan hak miliknya;"

Pasal 33 ayat (1) "Setiap orang berhak untuk bebas dari penyiksaan, penghukuman atau perlakuan yang kejam, tidak manusiawi, merendahkan derajat dan martabat kemanusiaannya."

Seringkali masyarakat adat tersingkir ketika negara/pemerintah dengan hak menguasai yang dimilikinya mengesampingkan hak masyarakat adat dalam pengelolaan sumber daya alam dengan alasan kepentingan nasional. Masyarakat adat sering dicap sebagai perusak lingkungan, kelompok masyarakat terbelakang, kuno, dan berbagai stigma negatif lainnya terkait aktivitas kehidupan sehariharinya yang memanfaatkan sumber daya alam. Masyarakat adat juga sering dipandang sebagai kelompok masyarakat penghambat pembangunan ketika mereka berusaha memperjuangkan hak-haknya atas sumber daya alam. Pelanggaran yang mereka alami adalah pelanggaran hak atas kepemilikan, hak atas makanan dan gizi yang mencukupi, hak terhadap standar hidup yang layak, hak untuk mengambil bagian dalam kehidupan kebudayaan, hak menentukan nasib sendiri, hak untuk menikmati standar tertinggi yang dapat dicapai atas 
kesehatan fisik dan mental, serta masih banyak hak lainnya, dimana hak-hak tersebut adalah merupakan Hak-hak asasi manusia (HAM). Menurut Yayasan Lembaga Bantuan Hukum Indonesia menyebut pada 2019 sebanyak 51 masyarakat adat yang telah dikriminalisasi karena perladangan lokal, dan penyebab dari kebakaran hutan dan lahan. YLBHI menuturkan di Kotawaringin Barat, Kalimantan Tengah sebanyak dua orang dikriminalisasi karena membakar lahan, lalu 11 orang yang merupakan suku anak dalam Jambi dituduh merusak dan menganiaya lingkungan sebagaimana dalam Pasal 17 pada Kitab UndangUndang Hukum Pidana (KUHP). Kemudian 27 masyarakat adat Wawonii Sulawesi Tenggara yang menolak aktivitas tambang terjerat Pasal 333 KUHP, enam orang peladang Sintang Kalimantan Barat terkena UU tentang lingkungan Hidup dan UU Perkebunan. Selanjutnya, dua orang masyarakat adat Tano Batak dituduh aniaya karyawan PT TPL. Lalu, dua orang masyarakat adat di Ketapang, Sumba, NTT dijerat karena pencemaran nama baik dan sisanya masyarakat Muara Teweh Kalimantan Tengah akibat pembakaran ladang. ${ }^{19}$

Terdapat juga kasus di Pubabu di Desa Linamnutu, Kecamatan Amanuban Selatan, Kabupaten Timor Tengah Selatan, Nusa Tengara Timur, di mana konflik lahan bermula pada 1982 ketika pemerintah dan Australia bekerja sama dalam peternakan dan penggemukan sapi dengan meminjam lahan masyarakat adat Setelah kontrak selesai, pengelolaan lahan itu semestinya dikembalikan ke masyarakat adat tetapi justru disertifikat hak pakai dengan luas sekitar 3.700 hektare. Pada 1982, pemerintah Australia menghendaki 6.000 hektar lahan untuk peternakan sapi tersebut. Namun karena hutan adat Pubabu hanya seluas 2.671,4 hektare, maka tetua adat pada saat itu sepakat untuk memasukkan belukar dan pekarangan masyarakat sehingga genap 6.000 hektar. Namun, pada 1985 pemerintah provinsi menerbitkan sertifikat di hutan adat Pubabu yang meliputi Desa Linamnutu, Mio dan Oe Ekam. Humas Pemprov NTT Marius Jelamu berdalih bahwa lahan itu sudah diserahkan oleh tetua adat kepada pemerintah daerah pada 1985 dan dibuat sertifikat atas lahan itu. Pada 1987, selama 25 tahun ke depan, wilayah itu digunakan sebagai areal proyek peternakan sapi. Pada 2010,

19 Ane, YLBHI: 51 Masyarakat Adat Kena Kriminalisasi Negara, Https://www.gatra.com/detail/news/ 461040/politik/ylbhi-51-masyarakat-adat-kena-kriminalisasi-negara, diakses 13 April 2021, jam 12.30 WIB. 
dua tahun sebelum kontrak kadaluarsa, tawaran perpanjangan dari Pemerintah Kabupaten Timor Tengah Selatan ditolak warga. Akan tetapi, pada 2012, pemerintah daerah kembali mengeluarkan serfitikat dengan luas 3.780 hektare, tanpa sepengetahuan masyarakat. Pada 2012, masyarakat Besipae menentang keputusan untuk memperpanjang izin atas tanah. Mereka berpendapat bahwa hutan adat diperlukan untuk dikembalikan ke fungsi aslinya sebagai kawasan konservasi yang oleh warga lokal dikenal sebagai Nais Kio. Kendati ada perlawanan dari masyarakat adat untuk melindungi hutan adatnya, Gubernur Nusa Tenggara Timur memutuskan untuk menjalankan rencananya mengembangkan kawasan itu sebagai area peternakan, perkebunan dan pariwisata. ${ }^{20}$

Hak-hak asasi manusia (HAM) adalah hak-hak yang (seharusnya) diakui secara universal sebagai hak-hak yang melekat pada manusia karena hakekat dan kodrat kelahiran manusia itu sebagai manusia. Menurut Dardji Darmodiharjo, seorang ahli filsafat Indonesia berpendapat bahwa Hak asasi manusia adalah hak dasar atau hak pokok yang dibawa manusia sejak lahir sebagai anugerah Tuhan Yang Maha Esa. ${ }^{21}$ Pada hakikatnya penghormatan dan perlindungan terhadap HAM ialah menjaga keseimbangan antara hak dan kewajiban, serta keseimbangan kepentingan perseorangan dengan kepentingan umum. ${ }^{22}$

Teori hukum hak asasi manusia berdasarkan yurisprudensi (case law) mensistematisasi dua kewajiban hukum utama bagi negara/pemerintah: primary rules yaitu the duty to abstain from infringing upon human rights, dan secondary rules yaitu the duty to guarantee respect of human rights. ${ }^{23}$ Kewajiban pertama (primary rules) dengan kewajiban negara untuk tidak melakukan pelanggaran hak asasi manusia baik melalui tindakan maupun pendiaman, termasuk menjamin pemenuhan secara aktif hak-hak tersebut. Kewajiban dalam primary rules masih dapat diklasifikasikan menjadi tiga bentuk yaitu: menghormati, melindungi dan memenuhi (to respect, to protect and to fulfil). Kewajiban menghormati

20 https://www.google.com/amp/s/www.bbc.com/indonesia/indonesia-53839101.amp diunggah 21 Juni 2021, pukul 12.49 WIB hlm. 2 .

21 Suprihatini, Pendidikan Kewarganegaraan kelas X Semester 1 untuk SMA/MA, Intan Pariwara, Klaten, 2012.

${ }^{22}$ Yudi Suparyanto, Deklarasi HAM di Indonesia, Cempaka Putih, Klaten, 2019, hlm. 3

${ }^{23}$ Muhammad Ashri, Hak Asasi Manusia Filosofi, Teorie Instrumn Dasar, Social Politic Genius, Makassar, 2018, hlm. 85 
mengharuskan negara menahan diri untuk tidak campur tangan dalam dinikmatinya hak; Kewajiban melindungi mengharuskan negara mencegah pelanggaran hak oleh pihak ketiga; Kewajiban memenuhi, mengharuskan negara mengambil tindakan-tindakan legislatif. Administratif, finansial, hukum dan tindakan lain yang memadai guna pelaksanaan hak sepenuhnya. ${ }^{24}$ Ini berarti negara tidak boleh melakukan tindakan-tindakan yang akan merugikan hak masyarakat adat dalam pengelolaan sumber daya alam. Misalnya pengusiran paksa masyarakat adat dari wilayah yang telah ditempati secara turun temurun hanya karena wilayah tersebut akan diberikan ijin HPH. Kemudian negara juga tidak boleh diam saja ketika terjadi pelanggaran oleh pihak ketiga terhadap masyarakat adat dalam pengelolaan sumber daya alam. Kewajiban kedua (secondary rules) berkenaan dengan kewajiban negara untuk mencegah pelanggaran, menyelidikinya ketika terjadi, melakukan proses hukum kepada pelaku serta melakukan reparasi atas kerugian yang timbul. Berkenaan dengan kewajiban negara pada awalnya diasumsikan berdasarkan gagasan Georg Jellinek mengenai "teori status" yang meliputi:25

a. Status Negativus = hak-hak liberal untuk tidak dicampur tangani.

b. Status Activus = hak-hak partisipasi demokrasi.

c. Status Positivus = hak-hak sosial yang menuntut aksi positif dari negara.

Bertolak dari asumsi tersebut, maka kewajiban negara terhadap HAM mencakup tiga hal, sehingga disebut "tripartit tipologi" yang menurut Henry Shue terdiri atas: obligations 'to avoid depriving: 'to protect from dewivation' dan 'to aid the deprived" Asbjorn Eide, juga menyatakan adanya tiga kewajiban negara yaitu obligations to respect, protect, dan fulfil, kemudian menambahkan obligation to facilitate, sehingga kewajiban negara menjadi empat.

Penentuan suatu perbuatan merupakan pelanggaran HAM atau berindikasi pelanggaran HAM dilakukan, pertama-tama, dengan mengingat waktu perbuatan tersebut dilakukan dan, kemudian, mengujinya terhadap peraturan perundang-undangan dan/atau instrumen internasional tentang atau yang berkaitan dengan HAM yang berlaku pada waktu dilakukannya perbuatan yang

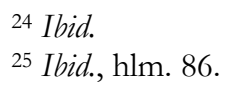


bersangkutan. Oleh karena itu, perlu kehati-hatian dalam melihat dan menilai dalam suatu peristiwa terjadi pelanggaran HAM.26 Terkait dengan kewajiban Pemerintah: 1) Pasal 28I ayat (4) UUD 1945 menyatakan: "Perlindungan, pemajuan, penegakan, dan pemenuhan hak asasi manusia adalah tanggung jawab Negara, terutama pemerintah". 2) Pasal 8 UU No, 39 Tahun 1999 tentang Hak Asasi Manusia menetapkan: "Perlindungan, pemajuan, penegakan, dan pemenuhan hak asasi manusia menjadi tanggung jawab pemerintah." 3) Pasal 71 UU No. 39 Tahun 1999 yang menyatakan: "Pemerintah wajib dan bertanggung jawab menghormati, melindungi, menegakkan, dan memajukan hak asasi manusia yang diatur dalam undang-undang ini, peraturan perundang-undangan lain, dan hukum internasional tentang hak asasi manusia yang diterima oleh negara Republik Indonesia,", dan Pasal 72 yang menyatakan: "Kewajiban dan tanggung jawab Pemerintah sebagaimana dimaksud dalam Pasal 71, meliputi langkah implementasi yang efektif dalam bidang hukum, politik, ekonomi, sosial, budaya, pertahanan keamanan negara, dan bidang lain. ${ }^{27}$ Pasal-pasal tersebutlah yang merupakan dasar hukum dalam melindungi masyarakat adat dari segala bentuk penindasan perampasan hak.

Negara yang berperan penuh dalam mendefinisikan, mengakui hingga melegitimasi eksistensi masyarakat adat sepanjang mereka mau "menuruti" regulasi negara. Paradigma ini tidak sesuai dengan prinsip kesetaraan dan otonomi yang ada dalam demokrasi. Pengakuan hak masyarakat adat seharusnya dikaitkan dengan substansi hak asasi manusia yang juga tercantum dalam UUD 1945 tentang Hak Asasi Manusia (HAM). Artinya, aturan yang ada tak sebatas meneguhkan pengakuan hak atas unit sosial tertentu (hak ulayat dan hak atas sumberdaya alam) sebagai hak konstitusional masyarakat adat. Namun, juga menjangkau hak-hak lain yang dijamin oleh konstitusi, yaitu hak atas jaminan kesehatan, hak atas pendidikan, hak untuk mengembangkan kehidupan dan budayanya, hak untuk setara di muka hukum dan pemerintahan, dan hak-hak asasi manusia lainnya. Ditambah lagi, ada proses yang disebut sebagai

26 Tim Inkuiri Nasional Komnas HAM, Inkuiri Nasional Komisi Nasional Hak Asasi Manusia: Hak Masyarakat Hukum Adat Atas Wilayahnya di Kawasan Hutan, Komisi Nasional Hak Asasi Manusia Republik Indonesia, Jakarta, 2016, hlm. 55.

${ }^{27}$ Ibid., hlm. 52. 
'negaraisasi hukum adat', yaitu memaksakan hukum negara (peraturan daerah, peraturan gubernur, dan peraturan lainnya) sebagai dasar hukum. Proses ini mengabaikan hukum adat yang sebenarnya sudah diterapkan oleh masyarakat adat secara turun-temurun.

Sebagaimana yang dapat penulis contohkan bahwa peraturan kementerian dalam negeri tentang kelembagaan adat desa di 2018. Aturan tersebut hanya mengurus adat istiadat, upacara seremonial, dan budaya tapi belum menyentuh aspek perlindungan hukum atau berlakunya hukum adat atau hukum lokal. Akibatnya, banyak peraturan tersebut justru menindas karena menyulitkan masyarakat adat kesulitan untuk mendapatkan hak-hak mereka.

Berdasarkan analisis di atas, maka telah nyata terjadi tumpah tindih peraturan dalam implementasi di lapangan menambah komplikasi perlindungan dan pemenuhan hak masyarakat adat. Alih-alih sebagai pengakuan dan perlindungan, kerap dijumpai masyarakat adat yang mengalami terus berbagai pelanggaran HAM. Oleh karena itu, perubahan yang perlu dilakukan pemerintah adalah mengubah pendekatan mereka dari yang berbasis hukum ke pendekatan berbasis hak. Artinya, pemerintah harus mengupayakan agar peran. Negara tidak menegasikan hukum rakyat. Pemerintah juga harus mendorong interaksi untuk mencegah dan melawan segala bentuk perampasan hak-hak masyarakat adat. Di titik itulah, jaminan perlindungan hak-hak sosial, budaya, lingkungan dan keberlanjutan ekologis, menjadi satu kesatuan dalam politik hukum yang lebih memberi perlindungan HAM bagi masyarakat adat secara universal.

\section{Penutup}

Berdasarkan hasil analisis para penulis, mengenai Undang-Undang Nomor 11 Tahun 2020 tentang Cipta Kerja yang terfokus pada pembahasan Pasal 35 tentang Kehutanan dalam aturan sebelumnya yang termaktub dalam UndangUndang Nomor 41 Tahun 1999 tentang kehutanan. Masyarakat Hukum adat hidup di sebuah wilayah hutan yang disebut dengan hutan adat, berdasarkan Pasal 1 angka 6 UU Kehutanan dijelaskan bahwa hutan adat adalah hutan negara yang berada dalam wilayah masyarakat hukum adat, kemudian setelah adanya Putusan Nomor 35/PUU-X/2012 dijelaskan Mahkamah Konstitusi menegaskan 
bahwa hutan adat bukan merupakan hutan negara, hal ini dikarenakan Pasal 1 angka 6 UU Kehutanan bertentangan dengan UUD 1945 Pasal 18B ayat (2) mengenai eksistensi penghormatan terhadap hak-hak masyarakat adat, maka dari itu dalam hal ini negara tidak memiliki kekuasaan hukum untuk menjadikan hutan adat adalah hutan yang berada di wilayah masyarakat hukum adat menjadi hutan negara.

Dengan adanya perkembangan hukum dan masyarakat yang kian pesat, namun membuat perubahan status masyarakat hukum adat belum berdampak secara sosial dan ekonomi, sehingga ciri masyarakat hukum adat masih terbelakang belum dapat dikesampingkan. Tugas Pemerintah Pusat untuk mengubah masyarakat hukum adat yang memiliki status hukum serta kewenangan menjadi sangat penting agar hak-hak masyarakat adat dapat terpenuhi. Akan tetapi, eksistensi mereka terancam di tengah banyak upaya penjarahan sumberdaya alam dan pengalihan fungsi hutan yang menyingkirkan hak-hak masyarakat adat salah satunya yaitu hak kemakmuran.

Dalam hal ini, pengakuan mengenai eksistensi masyarakat adat sebenarnya telah tertuang dalam dua pasal yang relevan di dalam Bab tentang Hak Asasi Manusia. Pasal 28G ayat (1) Pasal 28H ayat (4). Pasal-pasal khusus tentang masyarakat hukum adat juga merujuk pada Pasal 18B ayat (2) dan Pasal 28 I ayat (3) UUD NRI. Sehingga jika dikaitkan dengan Undang-Undang Kehutan yang sebelumnya bahwa aturan-aturan yang menjadi bahan evaluasi penulis ini lah yang menurut hemat penulis merupakan pasal-pasal yang sering terlupakan sehingga banyak hak kemakmuran rakyat tidak dipahami dan tidak diketahui sebagimana batasannya. Agar terciptanya aturan tentang Kehutanan harusnya dapat menjadikan aturan itu sebagai atauran yang berasaskan Lex Specialis Derogat Leghi Generaly, sehingga batas-batas yang bersifat umum dapat lebih terarah ke batasan yang sangat khusus. Pada realitanya Pemerintah telah membuat peraturan-peraturan yang berkaitan dengan perlindungan atas kemakmuran masyarakat hukum adat. Hal ini telah dijamin di dalam kontistusi dasar Negara Indonesia yakni Undang-Undang Dasar Negara Republik Indonesia tidak hanya di dalam Undang-Undang Dasar nyatanya telah banyak peraturan yang menyinggung terkait kemakmuran rakyat, baik dari segi pribadi maupun 
harta kebendaannya. Seperti halnya beberapa Pasal di dalam Undang-Undang Nomor 39 Tahun 1999 tentang Hak Asasi Manusia, yang pada intinya mereka memberikan perlindungan terhadap hak dan kebebasan, keadilan bagi masyarakat hukuum adat. Yang memang pada nyatanya tanah tersebut adalah hak mereka. Tetapi berdasarkan kasus yang telah diuraikan diatas meskipun pada nyatanya telah banyak peraturan-peraturan yang memberikan perlindungan tetapi dalam hal oknum atau pejabat yang berkuasa terkadang tidak mengalami sinkronisasi atas perbuatan dan peraturan yang telah ditetapkan. Seperti halnya konflik tanah di Hutan Adat Pubabu di Desa Linamnutu.

Di sini dapat dilihat dimana tanah mereka diambil dan terjadi perbuatan sewenag-wenang yang dilakukan oleh pemerintah dan mengingkari hak masyarakat ada. Di sini rekomendasi yang dapat penulis berikan yaitu masih perlu diperluas lagi mengenai bantuan hukum untuk masyarakat adat dan Putusan mengenai status hutan adat seharusnya tidak semata-mata dilihat dari kepentingan administratif. Status tersebut harus dilihat dalam perspektif hak asasi manusia terutama perspektif hak ekonomi, sosial dan budaya. Di samping itu, frase "sesuai dengan perkembangan masyarakat dan tidak bertentangan dengan prinsip negara Indonesia" juga harus diberikan penjelasan yang aplikatif, karena pembatasan ini bisa digunakan untuk melakukan penangguhan (derogation) atas hak adat secara sewenang-wenang. Kemudian dengan adanya konflik tersebut menjadi momentum untuk mengesahkan RUU Masyarakat Adat yang merupakan RUU yang sangat fundamental untuk perlindungan dan pemenuhan hak konstitusional masyarakat adat.

\section{Daftar Pustaka}

\section{Buku}

Helmi, Hukum Perizinan Lingkungan Hidup, cetakan I, Sinar Grafika, Jakarta, 2012.

Muhammad Ashri, Hak Asasi Manusia Filosofi, Teori \& Instrumen Dasar, Social Politic Genius, Makassar, 2018.

Soekanto, Soerjono, Hukum Adat Indonesia, Raja Grafindo, Jakarta, 2012.

Suparyanto, Yudi, Deklarasi HAM di Indonesia, Cempaka Putih, Klaten, 2019.

Suprihatini, Pendidikan Kewarganegaraan Kelas X Semester 1 untuk SMA/MA, Intan Pariwara, Klaten, 2012. 
Widowati, Dyah Ayu Widowati dkk., Pengakuan dan Perlindungan Hak Atas Tanah Masyarakat Hukum Adat di Kawasan Hutan,cetakan kedua, Pusat Penelitian dan Pengabdian kepada Masyarakat (PPPM), Yogyakarta, 2019.

\section{Artikel/Jurnal}

Cunduk Wasiati dan Hartanto, "Perizinan Sebagai Instrumen Pemanfaatan Hutan Masyarakat Hukum Adat", Jurnal Meta Yuridis, Vol.3 No.1, 2020,

Jawahir Thontowi, "Perlindungan dan Pengakuan Masyarakat Adat dan Tantangannya dalam Hukum Indonesia", Jurnal Hukum, Vol. 20, No.1, 2013.

Sugiswati, Perlindungan Hukum Terhadap Masyarakat Adat Indonesia", Prespektif, Vol. 17, No. 1, 2012.

Tim Inkuiri Nasional Komnas HAM,"Hak Masyarakat Hukum Adat Atas Wilayahnya di Kawasan Hutan", Komisi Nasional Hak Asasi Manusia Republik Indonesia, 2016.

Tobroni, "Menguatkan Hak Masyarakat Adat Atas Hutan Adat (Studi Putusan MK Nomor 35/ PUU-X/2012)", Jurnal Konstitusi, Volume 10, Nomor 3, 2013.

Yuliana, "Perlindungan Hak Masyarakat Adat dalam Melakukan Aktivitas Ekonomi, Sosial dan Budaya di Provinsi Maluku", Jurnal HAM, Vol. 8, No. 1, 2017.

\section{Internet}

"Asas-Asas Hukum Umum Dalam Penggunaan Tanah Untuk Sebesar-besarnya Kemakmuran Rakyat (Suatu Kajian Filsafati dan Teoritik Tentang Pengaturan dan Penggunaan Tanah di Indonesia)", e-book https://books.google.co.id, diakses 21 Maret 2020.

"Nasib Masyarakat Adat dalam UU Cipta Kerja", forestdigest.com, diakses pada 06 April 2020.

"Masyarakat adat Besipae di NTT yang 'digusur' dari hutan adat Pubabu: Anak-anak dan perempuan 'trauma' dan 'hidup di bawah pohon'" https://www.google.com/amp/s/www.bbc.com/indonesia/indonesia53839101.amp diakses 21 Juni 2021, pukul 12.49 WIB

"YLBHI: 51 Masyarakat Adat Kena Kriminalisasi Negara", Https:/ / www.gatra.com/ detail/news/461040/politik/ylbhi-51-masyarakat-adat-kenakriminalisasi-negara, diakses 13 April 2021, jam 12.30 WIB

\section{Peraturan Perundang-undangan}

Undang-Undang Nomor 41 Tahun 1999 tentang Kehutanan

\section{Putusan Pengadilan}

Putusan Mahkamah Konstitusi Republik Indonesia Nomor 35/PUU-X/2012 tentang Pengujian Undang-Undang Nomor 41 tahun 1999 tentang Kehutanan terhadap Undang-Undnang Dasar Negara Republik Indonesia Tahun 1945 